\title{
Problematika interpretace archivních mapových podkladů v prípadě mokřadních biotopů
}

\section{PAVEL RICHTER}

\author{
Klíčová slova: archivní mapy - mokřady - zadržení vody v krajině - nivy vodních toků - rybníky
}

\section{SOUHRN}

V tomto článku jsou představeny dostupné on-line archivní mapové podklady ze stránek Archivu Zeměměřického úřadu a Laboratoře geoinformatiky Fakulty životního prostředí Univerzity J. E. Purkyně v Ústí nad Labem, které poskytují přehled o historické lokalizaci mokřadních biotopů. Hlavní výzkumnou otázkou je potenciál využitelnosti jednotlivých mapových děl pro identifikaci historických mokřadů v České republice a vyhodnocení rozdílné interpretace mokřadních biotopů na těchto podkladech. Jsou zde prezentovány príklady znázornění mokřadů na historických mapových podkladech v horní části povodí Výrovky.

\section{ÚVOD}

V České republice je k dispozici velké množství různých archivních mapových podkladů, at už ve formě poskytování kopií za úplatu, pomocí WMS služeb, nebo jen pro prohlížení na webových aplikacích. Doposud tyto podklady byly rozptýleny na několika internetových stránkách rưzných institucí [1]. Nyní jsou dostupné téměř všechny na jednom místě - na webové aplikaci Archiv Zeměměřického úřadu [2]. Podklady jsou rozděleny do dvou základních skupin, a to "Archivní mapy" a "Letecké měřické snímky" (LMS). Po kliknutí do určitého místa v mapě se zobrazí dostupné archiválie, které je možno v aplikaci rovnou objednat. Nejzajímavější z hlediska zobrazení historického krajinného pokryvu jsou mapy stabilního katastru, Vojenské topografické mapy v systému S-1952 a Státní mapa 1:5000. Dále je tu sbírka map a plánů vydaných od poloviny 16. století do roku 1850. V sekci "Letecké měřické snímky“ jsou k dispozici LMS od třicátých do šedesátých let 20. století a od začátku 21. století momentálně do roku 2019. V této sekci jsou informace o konkrétních letech snímkování v oblasti od sedmdesátých let 20. století po začátek 21. století, ovšem na existenci konkrétního LMS z tohoto období, prípadně jeho získání, je potřeba vznést dotaz na zde uvedený e-mail (zu-obchod@cuzk.cz). Mapové listy Müllerova mapování a všech tří vojenských mapování jsou umístěny na stránkách Laboratoře geoinformatiky Fakulty životního prostředí Univerzity J. E. Purkyně v Ústí nad Labem [3]. Kromě samotných mapových listů je tu dostupný také klad mapových listů a interpretační klíč (ten pouze pro I. [4] a II. [5] vojenské mapování).

Samožrejmě mapy II. a III. vojenského mapování jsou mj. stále k dispozici na Národním geoportálu INSPIRE jako WMS služba [6]. Na webu Geografické služby AČR [7] se pořád ještě nachází sekce nabízející historické LMS, ale nyní již odkazuje prímo na stránky Archivu Zeměměřického úřadu [2].

\section{POPISOVANÉ ARCHIVNÍ MAPOVÉ PODKLADY}

\section{Müllerovo mapování}

Nejstarším tady prezentovaným mapovým podkladem je Müllerova mapa Čech z roku 1720, respektive Moravy z roku 1716 v měřítku přibližně 1 : 132000. Vznikla na základě vojenských, správních a hospodářských požadavků tehdejší monarchie. Při srovnání obsahu mapy s mladšími kartografickými prameny velkých a středních měřítek vypovídají Müllerovy mapy o tom, jak se měnila krajina poznamenaná vlivem prrírodních podmínek a činností člověka během staletí a co zůstalo v krajinné paměti do současnosti [8]. Nevýhodou pro podrobné srovnání vývoje krajiny s následujícími mapovými podklady je jeho nevyhovující prostorová presnost.

\section{První vojenské mapování}

Podkladem I. vojenského mapování byla Müllerova mapa zvětšená do měřítka 1 : 28 800. Byla zpracována na základě pouhého pozorování v terénu. Před mapováním nebyla z finančních a časových důvodů vybudována sít přesně určených trigonometrických bodů. Proto nebylo možné sestavit přehlednou mapu celé monarchie. Kresbu jednotlivých mapových listů nešlo jednoznačně napojit, bortila se nebo se překrývala. Význam I. vojenského mapování spočívá nejvíce $v$ jeho podrobnosti a v čase jeho zhotovení. Zachycuje území Čech, Moravy a Slezska jako celek před nástupem průmyslové revoluce, v době největšího rozkvětu kulturní barokní krajiny a její nejvyšší diverzity [9]. Stejně jako u Müllerova mapování je nevýhodou malá prostorová přesnost. V kliči k legendě I. vojenského mapování [4] jsou bažiny a mokřady znázorněny pomocí neohraničené tmavě modré vodorovné šrafy nepravidelné délky zpravidla na zeleném podkladě. Jsou zde odlišeny také zamokřené lesy (obr. 1). Dále jsou tu znázorněny louky a pastviny na vlhkých a mezických stanovištích hráškově zeleným tónováním. Vzhledem k nejasnému ohraničení těchto ploch v době mapování a také k následnému poškození některých mapových sekcí a obecně zestárnutí může tento mapový podklad sloužit pouze pro hrubou identifikaci či detekci mokřadů v dané lokalitě.

\section{Stabilní katastr}

Nejstarším využitelným mapovým podkladem s podrobným zobrazením mokřadů jsou mapy stabilního katastru, přesněji řečeno Indikační skici a z nich odvozené Císařské otisky. Je na nich zaznamenán historický stav krajiny 
Mokřady

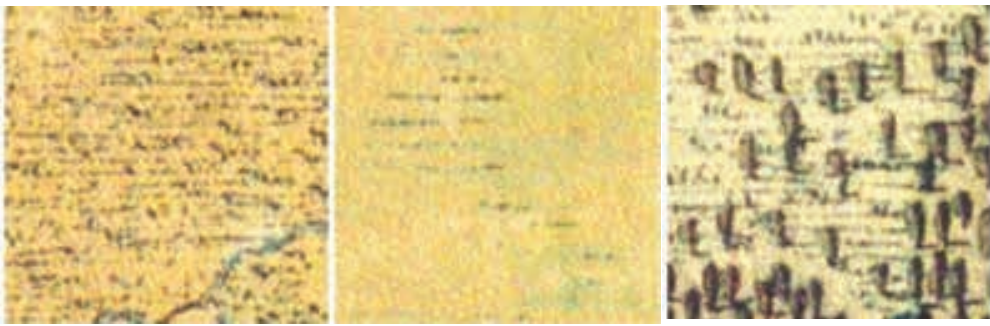

Obr. 1. Interpretace mokřadů (bez rybníků) na mapě I. vojenského mapování [4]

Fig. 1. Interpretation of wetlands (excluding ponds) on the map of I. Military mapping [4]

z poloviny 19. století. Mapy byly vyhotoveny v měřitku $1: 2880$, respektive $1: 5760$ v horských oblastech. Originální mapy byly pořizovány v terénu a zachycují skutečný stav krajiny před rozmachem průmyslové revoluce, tj. období 1824-1836 (Morava a Slezsko) a 1826-1843 (Čechy). Pro interpretaci stavu krajiny se využívají častěji Císařské otisky stabilního katastru. Indikační skici slouží pro upřesnění v prípadě nejasností anebo v prípadě, že se Císařské otisky nedochovaly. $\checkmark$ originální legendě Císařských otisků jsou čtyři základní zobrazení mokřadů: močály, močály s rákosovým porostem, mokré louky a rašeliniště [1, 10] (obr. 2). Mapy zobrazují také rybníky, které z definice patří mezi mokřady, ale zároveň jsou nejčastěji přiřazovány k vodním plochám. Při mapování stabilního katastru docházelo k různým odchylkám od předepsané legendy, nicméně téměř ve všech obdobích se vyskytují - kromě základního zobrazení mokrých luk - také mokré louky s dřevinami. Většinou se jedná o symbol listnatých stromů, stejný jako u zobrazení listnatých lesů. Existují však také mapové listy se symbolem ovocných stromů na podkladě mokrých luk, obdobně jako na zobrazení ovocných zahrad a polí nebo luk s ovocnými stromy [1]. Jejich nevýhodou pro využití k analýzám krajinných změn v prostředí GIS je nutnost georeferencování jednotlivých mapových listů, jelikož byly vytvářeny jako soubor obrázků, tzn. nespojených mapových listů.

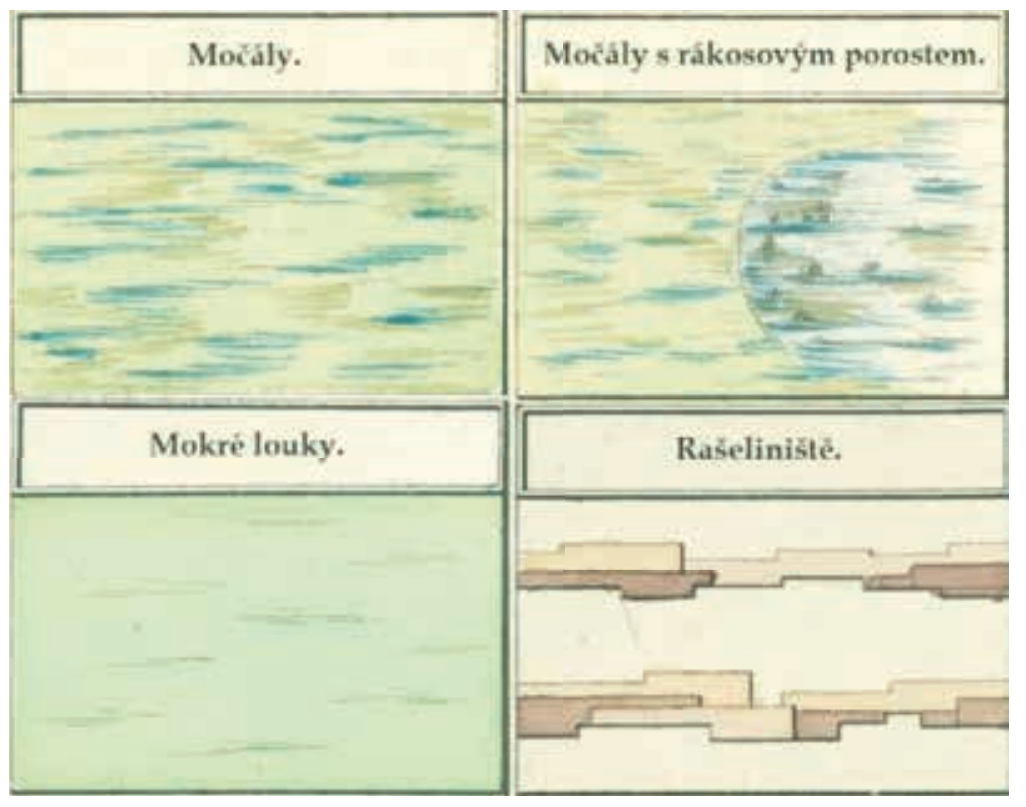

Obr. 2. Interpretace mokřadů (bez rybníků) v legendě Císařských otisků stabilního katastru $[1,10]$

Fig. 2. Interpretation of wetlands (excluding ponds) in the legend of the Imperial Imprints of the Stable Cadastre $[1,10]$

\section{Druhé vojenské mapování}

Pro primární detekci výskytu mokřadů je nejvhodnější relativně polohově přesná mapa II. vojenského mapování, zpracovaná v měřítku 1: 28800 [1]. Jejímu vzniku předcházela vojenská triangulace, jež sloužila jako geodetický základ tohoto díla; použitým podkladem byly mapy stabilního katastru, oproti I. vojenskému mapování se tedy zvýšila přesnost zobrazení. Obsah obou map je v podstatě totožný, avšak zobrazovaná situace se výrazně liší. Mapa II. vojenského mapování vznikala v době nástupu průmyslové revoluce a rozvoje intenzivních forem zemědělství, kdy výměra orné půdy vzrostla za 100 let o polovinu, plochy lesa dosáhly historicky nejmenšího rozsahu a jsou zde zaznamenány první železniční tratě [11]. V klíči k legendě u II. vojenského mapování [5] jsou bažiny a mokřady znázorněny podobně jako u l. vojenského mapování neohraničenou tmavě modrou vodorovnou šrafou, někdy doplněnou světle zeleným tónováním nebo symboly vegetace, a jsou tu opět odlišeny zamokřené lesy (obr. 3). Louky jsou vyznačeny různě sytou světle zelenou barvou, kde není jednoznačně určen stupeň podmáčení jednotlivých lokalit, uvažovalo-li se vůbec o něm. Vzhledem k nejasnému ohraničení těchto ploch $v$ době mapování a nejednoznačnosti v legendě ohledně mokřadů, ale zároveň i k celkem přesnému polohovému zobrazení může mapový podklad sloužit pro primární identifikaci či detekci mokřadů v dané lokalitě pro podrobné zpracování pomocí map stabilního katastru.

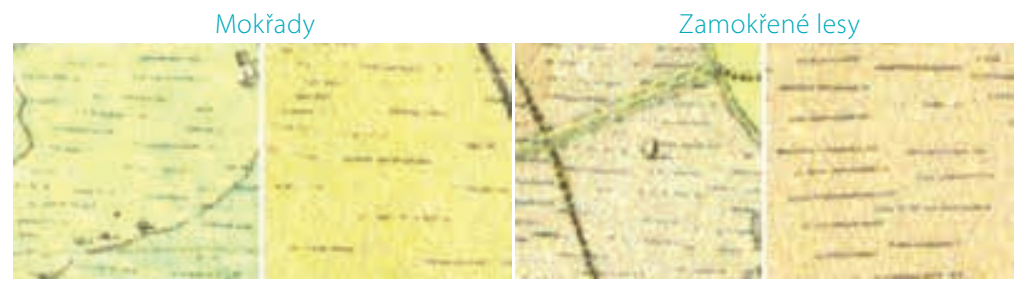

Obr. 3. Interpretace mokřadů (bez rybníků) na mapě II. vojenského mapování [5]

Fig. 3. Interpretation of wetlands (excluding ponds) on the map II. of Military mapping [5]

\section{Topografické mapy v systému S-1952}

Na webové aplikaci Archiv Zeměměřického úřadu [2] jsou tyto mapy k dispozici v měř́ku $1: 10$ 000, 1:25 000, 1:50 000, 1:100 000, 1:200 000 a 1:500 000. Pro detekci mokřadů $v$ krajině, respektive identifikaci krajinných změn, jsou nejvhodnější první dvě jmenované. Topografická mapa 1: 10000 byla zpracována a vydána na základě usnesení vlády č. 1391 z roku 1955 na celém území Československa, s výjimkou důležitých národohospodářských oblastí, kde byla zpracována topografická mapa 1: 5 000, a je zde zobrazen stav území v letech 1958-1971. Topografická mapa 1: 25000 byla zpracována a vydána na základě usnesení vlády č. 35 z roku 1953. Z těchto map byly postupně odvozeny topografické mapy měřitek 1: 50000 až 1:500 000 a zobrazují stav území v letech 1953-1960 [12]. V legendě topografických map v systému S-1952 jsou zaznamenány mokřady jako močály a bažiny neprůchodné nebo průchodné s uvedením jejich hloubky $v$ metrech a také jako mokřiny s rákosovým nebo orobincovým porostem či jen rákosové a orobincové porosty (obr. 4). Zajímavým doplněním je rovněž kategorie luční porosty nižší než 1 metr, které se často vyskytují v lokalitách, kde na mapách stabilního katastru byla mokrá louka [13].

\section{Státní mapa 1:5000}

Státní mapa 1: 5 000, vydávaná postupně od roku 1950, byla zamýšlena jako provizorium. Pro první vydání byl polohopis odvozen z katastrálních map a výškopis z nejvhodnějších existujících podkladů, napríklad z topografických map 
v systému S-1952. Až do roku 1990 tyto mapy nebyly určeny veřejnosti a směly se používat pouze pro vnitřní potřebu státních orgánů. Na webové aplikaci Archiv Zeměměřického úřadu [2] jsou tyto mapy $k$ dispozici ve verzích od padesátých let 20. století až po začátek 21. století, a jsou tak vhodným podkladem pro interpretaci archivních LMS.

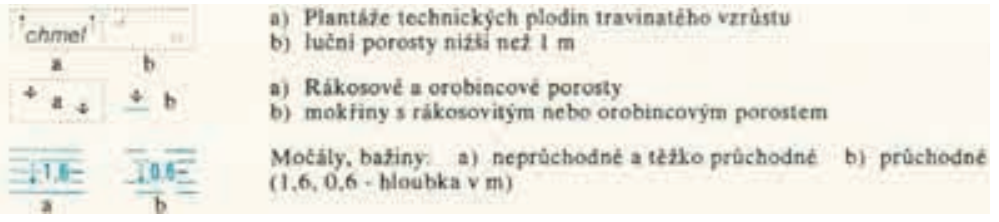

Obr. 4. Interpretace mokřadů (bez rybníků) v legendě Topografických map v systému

-1952 [13]

Fig. 4. Interpretation of wetlands (excluding ponds) in the legend of Topographic Maps

in the S-1952 system [13]

Archivní letecké měřické snímky - LMS

Jednotlivé snímky LMS je pro využití v GIS nutno georeferencovat. Jsou dostupné pro konkrétní lokalitu vždy podle toho, jak proběhlo snímkování v jednotlivých letech. Každý rok byla snímkována pouze část území, navíc některé snímky se nemusely dochovat. Na webové aplikaci Archivu Zeměměřického úřadu [2] v sekci „Letecké měřické snímky“ jsou k dispozici LMS od třicátých do šedesátých let 20. století a od začátku 21. století momentálně do roku 2019. Dále je zde informace o konkrétních letech snímkování v oblasti od sedmdesátých let 20. století po začátek 21. století. Získání archivních LMS, jež nejsou k dispozici na Archivu Zeměměřického úřadu, je možné na webu Geografické služby AČR [7].

\section{PŘÍKLADY INTERPRETACE KRAJINNÉHO POKRYVU NA POVODÍ VÝROVKY}

Prvním tady prezentovaným zobrazeným archivním mapovým podkladem je horní (pramenná) část povodí Výrovky na Müllerově mapě Čech z roku 1720. Nevýhodou tohoto díla je samožrejmě polohová nepřesnost, nicméně dobře poslouží k utvoření představy o podobě krajiny v tomto období. Nejzajímavější je zobrazení vodních toků a ploch (rybníků). Na základě interpretace pozdějších mapových podkladů je možné celkem přesně zobrazit sít vodních ploch v roce 1720. U vodních toků tomu tak již není, na území zcela chybí zobrazení Výrovky nad Uhliřskými Janovicemi (lanowitz) a na mapě je pouze Anenský potok (pramení u Sudějova) a Ostašovský potok, v jehož pramenné oblasti se nachází trojice rybníků. Nicméně vodní toky jsou tu schematicky znázorněny jako meandrující, což zcela jistě odpovídá historické skutečnosti (obr. 5).

Stejná oblast je zobrazena na mapě I. vojenského mapování, která je zpracována v podrobnějším měřítku, a tak zde již Výrovka nad Uhlî́skými Janovicemi (Janowitz) zaznamenána je. Opět jsou tu znázorněny meandrující vodní toky a v nivě jsou již zobrazeny luční porosty, případně bažiny. Totéž platí i o vodních plochách (rybnících). Oproti Müllerovu mapování jsou tady věrněji zobrazeny rozlohy sídel a lesních porostů. Na základě interpretace této mapy je pravděpodobné, že níže popisovaná lokalita U Stratinek byla v tomto období obklopena lesem, nikoli ornou půdou (obr. 6). Na obr. 7 je zachycen stav bažin a močálů v okolí rybníků na území Chmeliště a Bláta. Také v této zóně je více lesních porostů než v současnosti.

Na příkladu nivy Výrovky na hranici k. ú. Uhlî̌ské Janovice a Žišov je znázorněn rozdíl v zakreslování mokřadů na mapách I. vojenského mapování a stabilního katastru. Zatímco I. vojenské mapování zachycuje v nivě luční porosty a zde v jedné lokalitě bažinu, na stabilním katastru jsou v nivě zobrazeny mokré

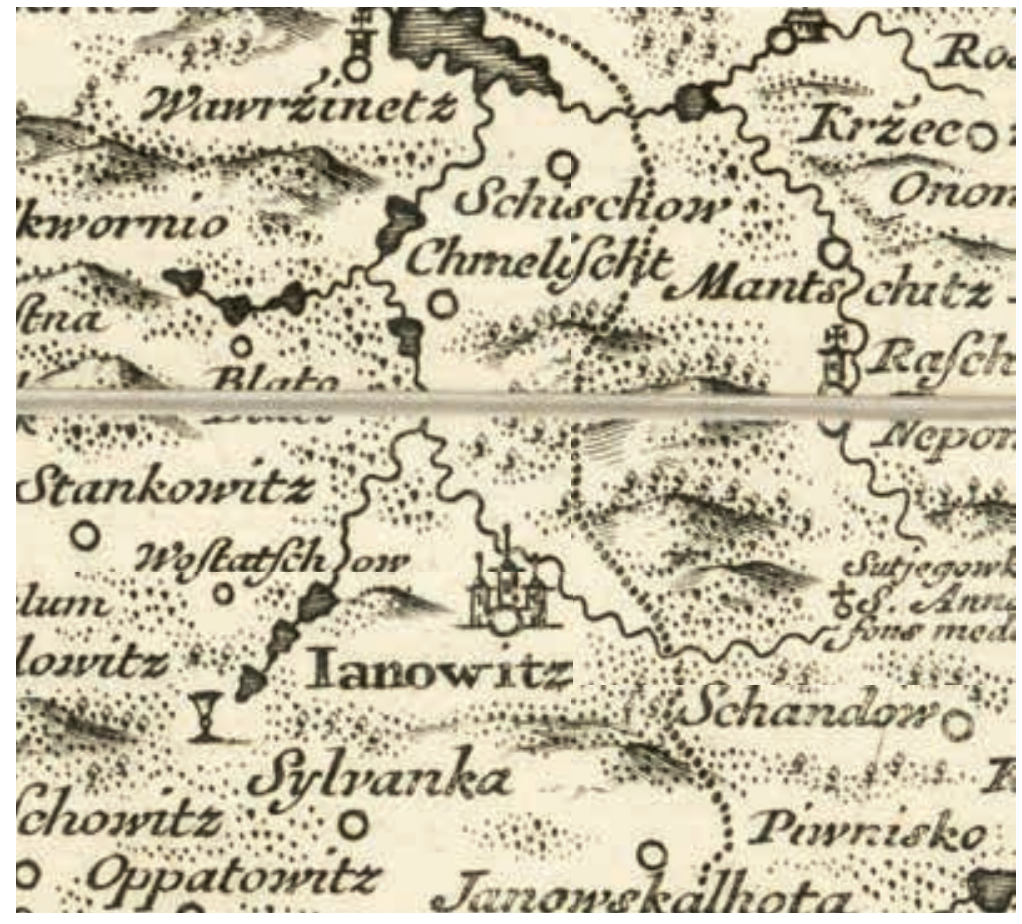

Obr. 5. Zobrazení horní (pramenné) části povodí Vúrovky na Müllerově mapování [15]

Müller's mapping [15]

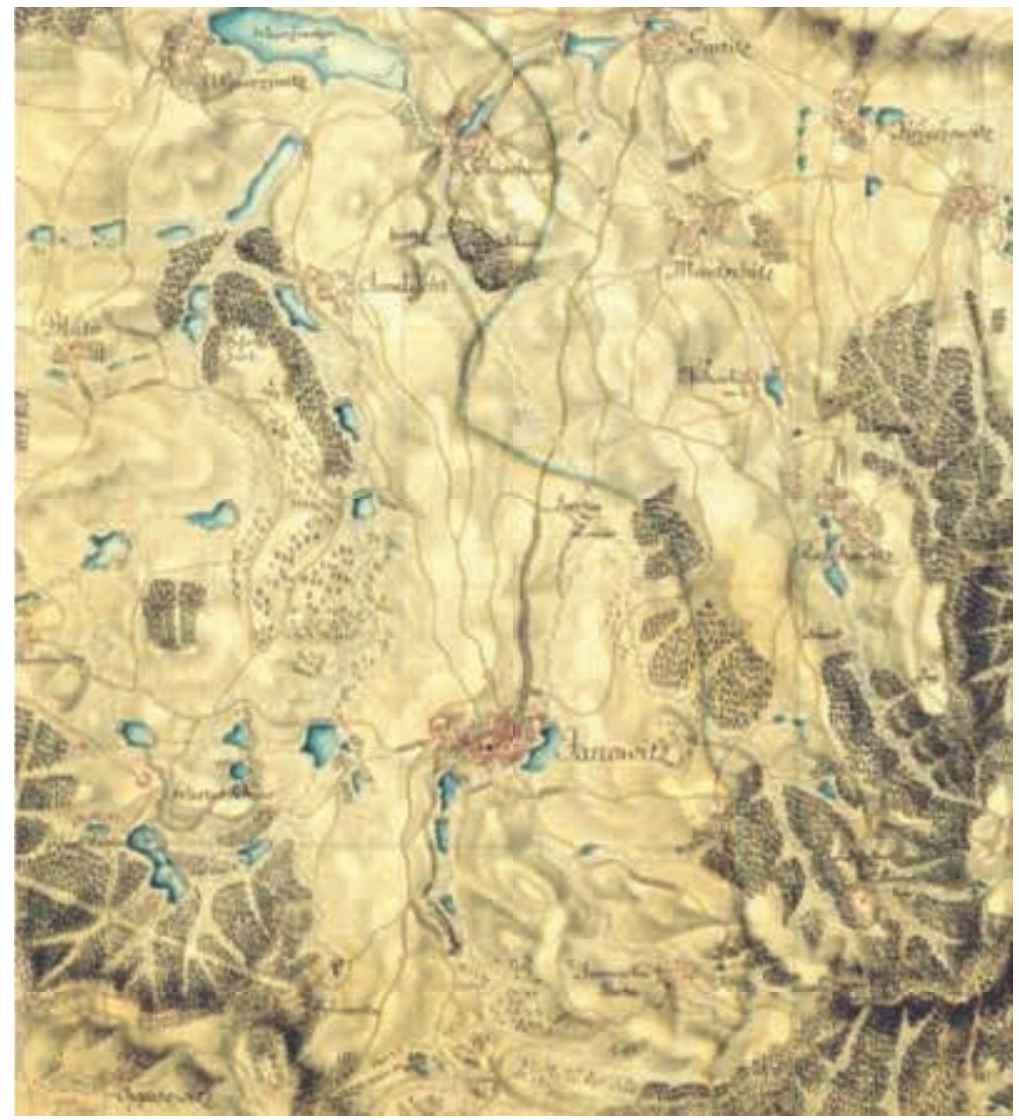

mapování [16]

Fig. 6. Depiction of the upper (source) part of the Výrovka River basin on the map

f. Military mapping [16] 


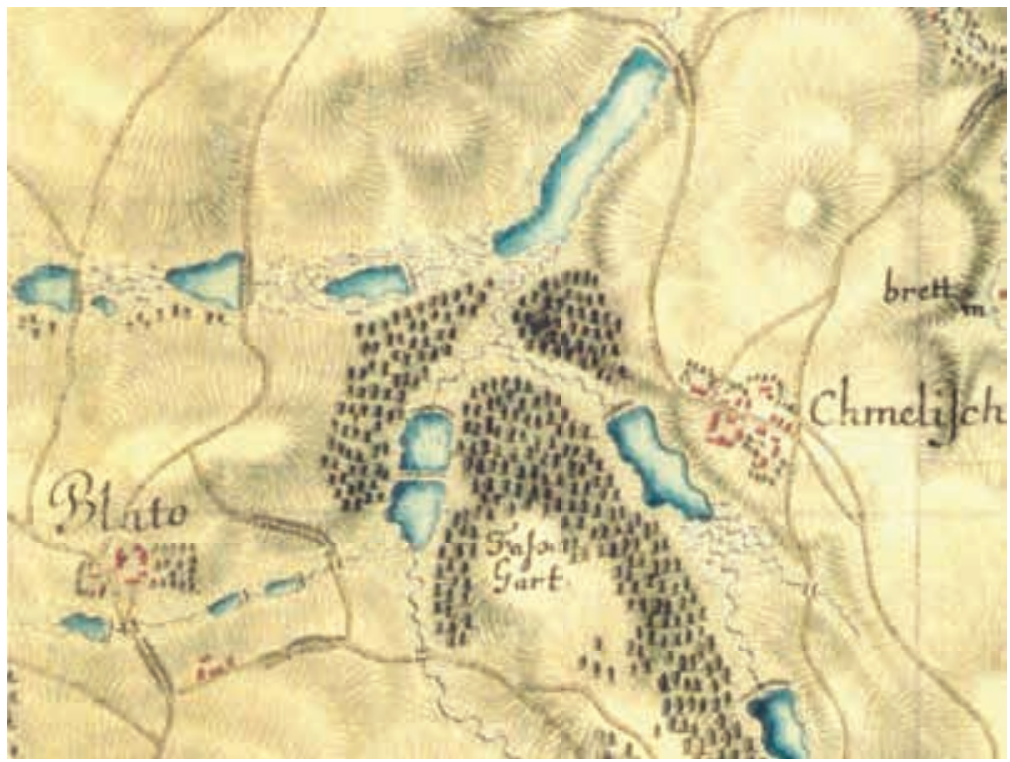

Obr. 7. Př́klad zobrazení bažin a močálů v okolí rybníků na mapě I. vojenského mapování na území současných k. ú. Chmeliště a Bláto [16]

Fig. 7. Example of depiction of swamps around ponds on the map of I. Military mapping in current cadastral territories of Chmeliště and Bláto [16]

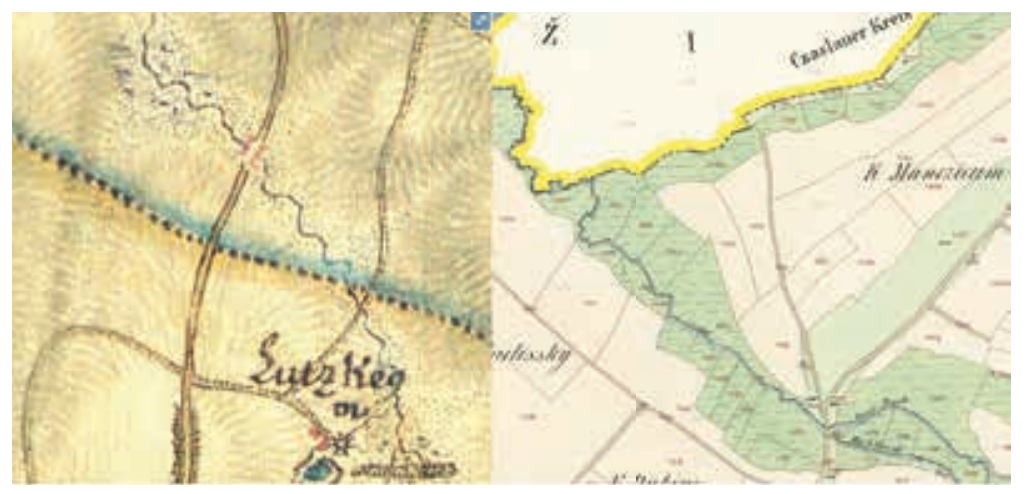

Obr. 8. Príklad rozdílné interpretace mokřadů v nivě Výrovky na mapě I. vojenského mapování [16] a na Císařských otiscích stabilního katastru na hranici k. ú. Uhlírské Janovice a Žíšov [17]

Obr. 8. Example of different interpretation of wetlands in Výrovka River floodplain on the map of I. Military mapping [16] and on the Imperial Imprints of the Stable Cadastre on the border of cadastral territories of Uhlírské Janovice and Žíšov [17]

louky (obr. 8). Na mapách stabilního katastru obecně v nivách vodních toků převažují mokré louky, v některých lokalitách mokré louky s dřevinami a občas se v nivách vyskytují louky "suché”.

Níže je podrobněji prezentována lokalita U Stratinek, nacházející se v k. ú. Rašovice u Uhliřských Janovic. Na Indikačních skicách i Císařských otiscích stabilního katastru jsou v lokalitě zakresleny mokré louky, konfigurací indikující prameniště. V mapách stabilního katastru nebyly často uváděny drobné vodní toky, proto Ize na základě těchto podkladů o prameništi jenom spekulovat. Na Topografické mapě 1: 10000 z roku 1952 již drobný vodní tok zaznamenán je, ale na Topografické mapě $1: 25000$ z roku 1956 a na Státní mapě $1: 5000$ z roku 1962 tam opět není. Na všech těchto podkladech z 20. století je v lokalitě zanesen luční porost (obr. 9). Na obr. 10 je porovnání zakreslení lokality U Stratinek na současné Základní mapě České republiky 1:10 000 (ZM 10) a mapě II. vojenského mapování 1: 28 800. V současnosti je na mapě ZM 10 jenom orná pưda a na mapě II. vojenského mapování je zakreslena rozsáhlá lokalita lučních porostů, ačkol historická mapa je v méně podrobném měřítku. Současná ortofotomapa (2019)

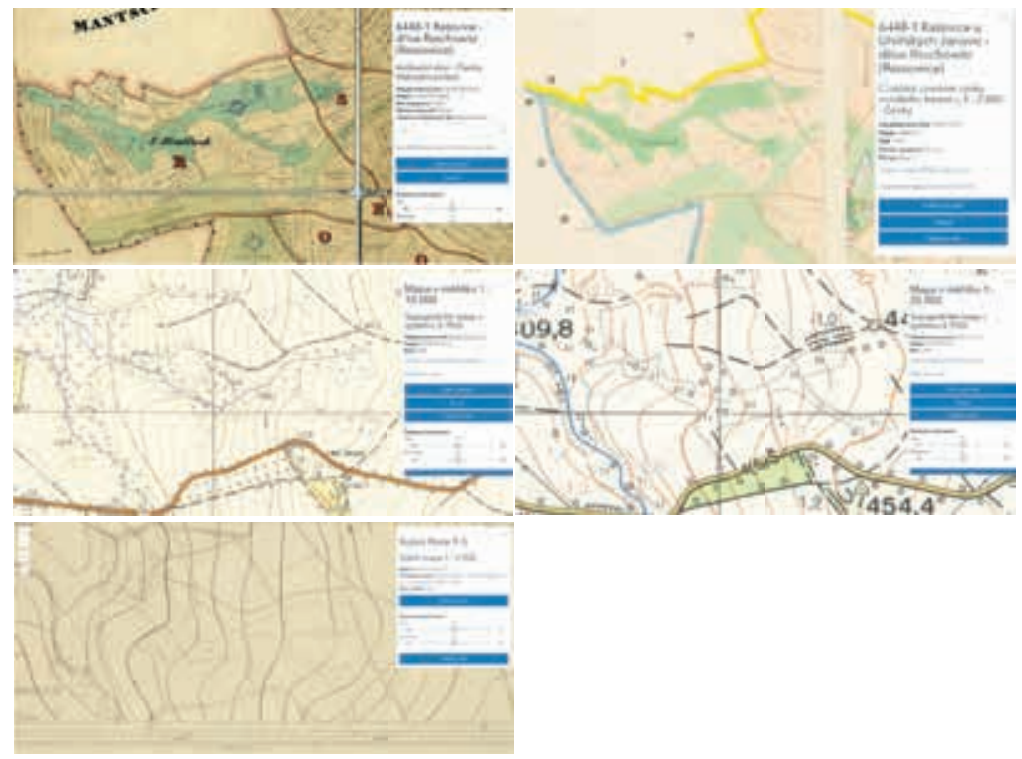

Obr. 9. Příklad rozdílné interpretace krajinného pokryvu v lokalitě U Stratinek v k. ú. Rašovice na Indikačních skicách [18] a Císařských otiscích stabilního katastru [19], na Topografických mapách v systému S-1952 1: 10000 [20] a 1:25000 [21] a na Státní mapě $1: 5000$ (1962) [22]

Fig. 9. Example of different interpretation of land cover in the place $U$ Stratinek in cadastral territory of Rašovice on Indication sketches [18] and Imperial Imprints of the Stable Cadastre [19], on Topographic maps in the S-1952 system 1: 10000 [20] and 1:25000 [21] and on the State map 1:5000 (1962) [22]

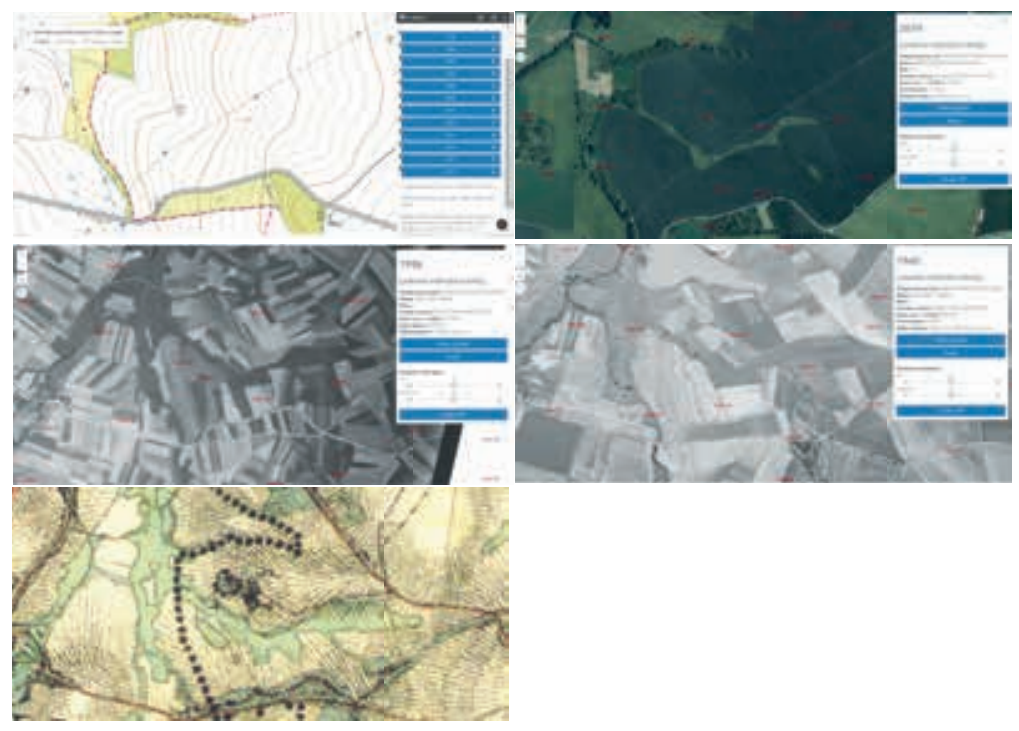

Obr. 10. Lokalita U Stratinek v k. ú. Rašovice na současné Základní mapě ČR 1: 10000 [2], současné ortofotomapě (2019) [23], na leteckých měřických snímcích z let 1938 [24] a 1960 [25] a na mapě II. vojenského mapování [26]

Fig. 10. Place U Stratinek in cadastral territory of Rašovice on the current Basic Map of the Czech Republic 1: 10000 [2], the current orthophotomap (2019) [23], on archival aerial photographs from years 1938 [24] and 1960 [25] and on the map of II. Military mapping [26]

zobrazuje v této lokalitě luční ekosystém, který byl při terénním průzkumu potvrzen jako prameniště. Nicméně současný stav lokality není výsledkem cíleného managementu, ale pouze odrazem aktuálního stavu pưdy, která neumožňuje obdělávání [1]. Pro porovnání je na obr. 10 lokalita u Stratinek zobrazena také na LMS z let 1938 a 1960. Je patrné, že prameniště tu bylo v obdobném 
rozsahu na obou snímcích. Rozdílem mezi oběma obdobími je zvětšení rozloh obhospodařovaných pozemků, ačkoli oproti současnosti je stav v roce 1960 mnohem príznivější.

Coby príklad interpretace mokřadů na obdobných podkladech jako v lokalitě u Stratinek byla vybrána oblast u rybníka Stojespal a u Mlékovického rybníka na vodním toku Bečvárka v povodí Výrovky. Na Císařských otiscích stabilního katastru jsou u obou rybníků zakresleny mokré louky, u Mlékovického rybníka navíc doplněné kresbou močálu. Pod hrází Mlékovického rybníka je zakreslena bažina na pastvině. Na Topografické mapě 1 : 10000 z roku 1967 je před Mlékovickým rybníkem zakreslena bažina (částečně s rákosovým nebo orobincovým porostem) na obdobném místě jako na stabilním katastru; další zobrazení se liší, bažina není pod hrází Mlékovického rybníka, nýbrž před rybníkem Stojespal. V nivě Bečvárky jsou znázorněny luční porosty. Na Topografické mapě 1: 25000 z roku 1956 ani na Státní mapě 1: 5000 z roku 1969 bažiny nejsou zakresleny, ale zobrazení lučních porostů odpovídá předchozí mapě (obr. 11).

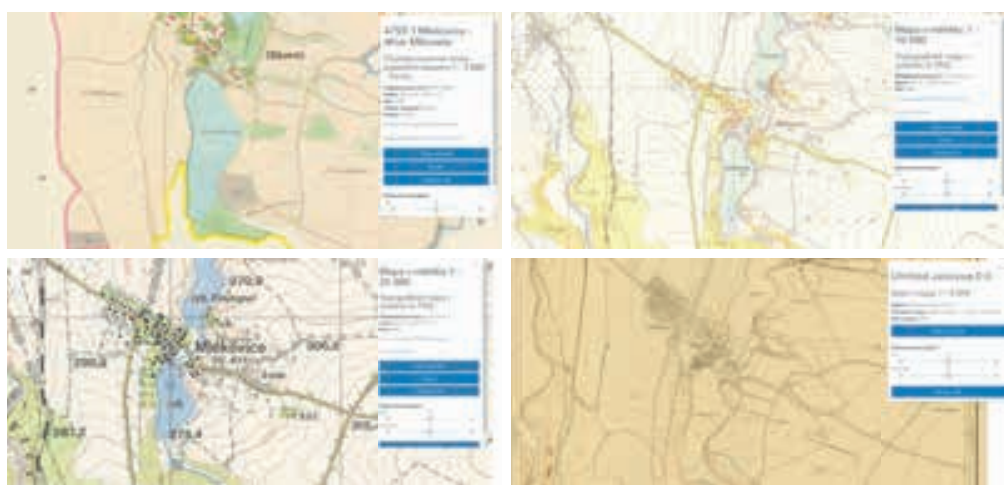

Obr. 11. Příklad interpretace mokřadů u rybníka Stojespal a u Mlékovického rybníka na Císařských otiscích stabilního katastru [27], na Topografických mapách v systému S-1952 $1: 10000$ [28] a 1:25000 [29] a na Státní mapě 1: 5000 (1969) [30]

Fig. 11. Example of interpretation of wetlands around Stojespal pond and Mlékovice pond on Imperial Imprints of the Stable Cadastre [27], on Topographic maps in the S-1952 system 1:5000 [28] and 1:25000 [29] and on the State map 1:5000 (1969) [30]

\section{DISKUZE A ZÁVĚR}

Článek se zabývá archiváliemi, jež jsou bezproblémově on-line přístupné, což umožňuje jejich široké uplatnění. Popisuje stránky, které zachytily současný trend digitalizace různých archivních fondů a materiálů. Jedním z cílů bylo jednoduše a přehledně popsat současnou situaci a pomoci s orientací v problematice archivních mapových podkladů týkajících se mokřadů a vody v krajině. Mezi archivními mapovými podklady, jež poskytují přehled o historické lokalizaci mokřadních biotopů (včetně rybníků), jsou značné rozdíly jak v polohové presnosti, tak ve způsobu interpretace krajinného pokryvu, respektive v kategorizaci podmáčených biotopů. Všechny zde představené archivní mapové podklady mají velký potenciál využitelnosti pro identifikaci historických mokřadů na území České republiky, avšak spíše při jejich vzájemné kombinaci nebo doplnění údajů, které na některém podkladě chybí. Výjimkou je Müllerovo mapování, kde Ize smysluplně využít zřejmě jen zobrazení vodních ploch (rybníků) jako doplněk k novějším podkladům. Vodní toky tu nejsou zakresleny všechny.

Jednotlivé mapové podklady při vzájemném porovnávání nelze brát zcela nekriticky z důvodu rozdílné interpretace krajinného pokryvu, respektive mokřadních biotopů zakreslených v těchto podkladech.

Mapy I. a II. vojenského mapování mají kategorii podmáčené lesy a nejsou $\checkmark$ nich úplně jasně rozlišovány typy lučních porostů z hlediska jejich zamokření. Na mapách stabilního katastru jsou typy lučních porostů naopak kategorizovány a vyskytuji se tu mokré louky, ale zase ne podmáčené lesy. Další mapové podklady nerozlišují typy luk na mokré a "suché" a v rámci zobrazení bažin je hranice většinou neostrá. V Topografických mapách v systému S-1952 1: 10000 jsou zobrazovány všechny drobné vodní toky, v jiných podkladech nikoli. Při nesprávné interpretaci archivních mapových podkladů by vodní toky mohly mizet a zase se objevovat, stejně tak podmáčené lesy nebo bažiny. Taktéž by se na mapách stabilního katastru ve velkém počtu objevovaly a $v$ dalších letech pak mizely i mokré louky. Ovšem z kritického srovnání historických a současných podkladů Ize vyvodit, že mokré louky od padesátých let 20. století z naší krajiny opravdu téměř zmizely. $V$ podstatě Ize jen polemizovat o tom, zda to je z hlediska krajinných funkcí a vody v krajině opravdu podstatná negativní změna, když jsou historické mokré louky $v$ současnosti lokalizovány na "Suchých" loukách anebo v křovinách, prípadně v lese.

$\checkmark$ príspěvku jsou prezentovány príklady znázornění mokřadů na historických mapových podkladech $v$ horní části povodí Výrovky, kde jsou výše popsané rozdíly a z nich pramenící potenciální nepresnosti při doslovné interpretaci mapových podkladů znázorněny na konkrétních lokalitách. Např. v lokalitě U Stratinek by se prí takové interpretaci z mokrých luk staly pouze louky "suché" a v padesátých letech 20. století by se tam objevil a poté zmizel drobný vodní tok. Z doplňujících analýz této lokality [1] je zřejmé, že zde bylo historicky prameniště, jež bylo zlikvidováno a postupně preměněno na ornou půdu melioracemi na prelomu sedmdesátých a osmdesátých let 20. století. Na počátku 21. století přestávají meliorace plnit svou funkci, podmáčenou půdu již nelze soudobou technikou obhospodařovat a za pomoci sukcese se tu prameniště opět obnovilo. Topografické mapy v systému S-1952 a Státní mapa 1: 5000 společně s historickými LMS ukazují, že na současných velkých plochách orné půdy bylo ještě během šedesátých a sedmdesátých let 20. století (tedy již $v$ rámci kolektivizace a scelování pozemků) velké množství drobných lokalit s lučními porosty (tyto podklady nerozlišovaly louky podle zamokrení), které se vyskytovaly prevážně ve stejných či obdobných lokalitách, kde byly na mapách stabilního katastru zakresleny mokré louky. V př́spěvku je prezentováno pouze několik lokalit jako príklad, nicméně existuje řada dalších obdobných oblastí, které potvrzují, že se jednalo o trend ve způsobu hospodaření v krajině na území České republiky.

Samožrejmě že na téma digitalizace archivních mapových podkladů nebo hodnocení vývoje krajiny na základě jejich interpretace existuje velké množství literárních zdrojů, např. príspěvek s informacemi o digitalizaci mapové sbírky Geografického ústavu Masarykovy univerzity [31]. Tématem využití informací ze starých map se zabýval např. Russnák et al. [32], Havlíček et al. [33], Trpáková [34], Kupka [35], Semotánová [36, 37, 38] nebo Moreira et al. [39]. Archivní mapové podklady pro vyhodnocení krajinného vývoje konkrétního území využili např. Lipský pro Novodvorsko a Žehušicko [40, 41], Trpáková et al. pro Sokolovsko [42] nebo Gimmi et al. pro analýzu zmizelých mokřadů v nižinách Švýcarska [43].

Závěrem Ize potvrdit vhodnost využití v príspěvku uvedených mapových podkladů při navrhování (obnově) ekologicky významných prvků (EVP) či prostě prvků pro zvýšení ekologické stability současné krajiny pro zadržování vody $\checkmark$ krajině, at již $v$ rámci plánu společných zařízení při pozemkových úpravách $[44,45]$, nebo vymezování skladebných částí ÚSES (Územní systém ekologické stability), zejména interakčních prvků [46, 47]. Historická lokalizace takových prvků je silným argumentem pro jejich obnovu, zejména při současné klimatické změně. Navíc i v současném systému vyplácení dotací subjektům hospodařícím na zemědělské půdě $[48,49]$ se $s$ takovými prvky v rámci vymezování EVP v LPIS (registr půdy sloužící k evidenci zemědělské půdy za účelem vyplácení dotací) počíá, i když v minimalistickém rozsahu. 


\section{Literatura}

[1] RICHTER, P. Mokřady na archivních mapových podkladech. Vodohospodářské technicko-ekonomické informace, 2020, 62 (4), s. 30-37. ISSN 0322-8916.

[2] Archiv Zeměměřického úřadu [on-line]. [cit. 25. červen 2021]. Dostupné z: https://ags.cuzk.cz/archiv/

[3] Laboratoř geoinformatiky Fakulty životního prostředí Univerzity J. E. Purkyně v Ústí nad Labem [on-line]. [cit. 29. červen 2021]. Dostupné z: http://oldmaps.geolab.cz

[4] Laboratoř geoinformatiky Fakulty životního prostředí Univerzity J. E. Purkyně v Ústí nad Labem. Klíč k legendě k I. vojenského mapování [on-line]. [cit. 25. červen 2021]. Dostupné z: http://projekty. geolab.cz/oldmaps/vav_mzp/klic1.htm

[5] Laboratoř geoinformatiky Fakulty životního prostředí Univerzity J. E. Purkyně v Ústí nad Labem. Klíč k legendě k II. vojenskému mapování [on-line]. [cit. 25. červen 2021]. Dostupné z: http://projekty. geolab.cz/oldmaps/vav_mzp/klic2.htm

[6] Národní geoportál INSPIRE/WMS služby [on-line]. [cit. 8. červen 2021]. Dostupné z: https:// geoportal.gov.cz/web/guest/wms

[7] Geografická služba AČR. Historické LMS [on-line]. [cit. 15. květen 2021]. Dostupné z: http://www. mapy.army.cz/historicke-Ims

[8] Laboratoř geoinformatiky Fakulty životního prostředí Univerzity J. E. Purkyně v Ústí nad Labem. Müllerovo mapování [on-line]. [cit. 29. červen 2021]. Dostupné z: http://oldmaps.geolab.cz/map_ root.pl?lang=cs\&map_root=mul

[9] Laboratoř geoinformatiky Fakulty životního prostředí Univerzity J. E. Purkyně v Ústí nad Labem. I. vojenské mapování [on-line]. [cit. 29. červen 2021]. Dostupné z: http://oldmaps.geolab.cz/map_ root.pl?lang=cs\&map_root=1vm

[10] Císařsképovinnéotiskystabilního katastru, legenda kmapě (přeložená) [on-line]. [cit.8. květen2021] Dostupné z: https://ags.cuzk.cz/archiv/openmap.html?typ=legendy\&idrastru=cio_legenda_cs

[11] Laboratoř geoinformatiky Fakulty životního prostředí Univerzity J. E. Purkyně v Ústí nad Labem. II. vojenské mapování [on-line]. [cit. 29. červen 2021]. Dostupné z: http://oldmaps.geolab.cz/map_ root.pl?lang=cs\&map_root=2vm

[12] Zeměměřický úřad. Topografické mapy v systému S-1952 [on-line]. [cit. 30. červen 2021]. Dostupné z: https://uazk.cuzk.cz/vademecum_mapy/NavigBean.action?entity=\%28\%5En\% 29\%28\%28\%28localArchiv\%2C\%5En\%2Chot_\%29\%28 unidata\%29\% 29\%28192967\%29\%29

[13] Zeměměřický úřad. Topografické mapy $v$ systému S-1952, legenda k mapě [on-line]. [cit. 30. červen 2021]. Dostupné z: https://ags.cuzk.cz/archiv/openmap.html?typ=legendy\&idrastru $=$ topos52_legenda

[14] Geoportál ČÚZK. Státní mapa $1: 5000$ [on-line]. [cit. 1. červenec 2021]. Dostupné z: https:// geoportal.cuzk.cz/(S(scrcejdau2acoel0drbszz0k))/Default.aspx?mode=TextMeta\&side=mapy5\&text $=$ dsady_mapy5\&menu=222

[15] Laboratoř geoinformatiky Fakulty životního prostředí Univerzity J. E. Purkyně v Ústí nad Labem. Müllerovo mapování - Čechy, mapový list č. 13 [on-line]. [cit. 1. červenec 2021]. Dostupné z: http:// oldmaps.geolab.cz/map_viewer.pl?lang=cs\&map_root=mul\&map_region=ce\&map_list=c013 ๑) Historický ústav AV ČR- http://www.hiu.cas.Cz

[16] Laboratoř geoinformatiky Fakulty životního prostředí Univerzity J. E. Purkyně v Ústí nad Labem. l. vojenské mapování - Čechy, mapový list č. 145 [on-line]. [cit. 1. červenec 2021]. Dostupné z: http:// oldmaps.geolab.cz/map_viewer.pl?lang =cs\&map_root=1vm\&map_region=ce\&map_list=c145 (c) 1st Military Survey, Section No. 145, AustrianStateArchive/Military Archive, Vienna @ Laboratořgeoinformatiky Univerzita J. E. Purkyně - http://www.geolab.cz @ Ministerstvo životního prostředi ČR-http://www.env.cz

[17] Archiv Zeměměřického úřadu. Císařské povinné otisky stabilního katastru 1:2880 - Čechy, 8184-1 Uhliŕské Janovice, list 2 [on-line]. [cit. 2. červenec 2021]. Dostupné z: https://ags.cuzk.cz/archiv/ openmap.html?typ=cioc\&idrastru=B2_a_6C_8184-1_2

[18] Archiv Zeměměřického úřadu. Indikační skici - Čechy, 6448-1 Rašovice [on-line]. [cit. 2. červenec 2021]. Dostupné z: https://ags.cuzk.cz/archiv/openmap.html?typ=skicic\&idrastru=CAS473018380

[19] Archiv Zeměměřického úřadu. Císařské povinné otisky stabilního katastru 1:2880 - Čechy, 6448-1 Rašovice u Uhliřských Janovic, list 1 [on-line]. [cit. 2. červenec 2021]. Dostupné z: https://ags.cuzk.cz/ archiv/openmap.html?typ=cioc\&idrastru=B2_a_6C_6448-1_1

[20] Archiv Zeměměřického úřadu. Topografické mapy v systému S-1952 1: 10 000, list D7_2__M-3379-A-c-2 [on-line]. [cit. 7. červenec 2021]. Dostupné z: https://ags.cuzk.cz/archiv/openmap.html?typ= topo1952\&idrastru=D7_2__M-33-79-A-C-2

[21] Archiv Zeměměřického úřadu. Topografické mapy v systému S-1952 1:25 000, list D7_3__M-3379-A-c [on-line]. [cit. 7. červenec 2021]. Dostupné z: https://ags.cuzk.cz/archiv/openmap.html?typ=to po1952\&idrastru=D7_3__M-33-79-A-C

[22] Archiv Zeměměřického úr̆adu. Státní mapa 1: 5 000, list Kutná Hora 9-5, rok 1952 [on-line]. [cit. 7. červenec 2021]. Dostupné z: https://ags.cuzk.cz/archiv/openmap.html?typ= sm5\&idrastru=D6-1_Kutna_Hora_9-5_1952

[23] Archiv Zeměměřického úřadu. Letecké měřické snímky, WMSD24.2019.KUTH96.00540 [on-line] [cit. 8. červenec 2021]. Dostupné z: https://ags.cuzk.cz/archiv/openmap.html?typ=Ims\&idrastru =WMSD24.2019.KUTH96.00540
[24] Archiv Zeměměřického úřadu. Letecké měřické snímky, WMSA08.1938.KUTH96.08897 [on-line]. [cit. 9. Červenec 2021]. Dostupné z: https://ags.cuzk.cz/archiv/openmap.html?typ=Ims\&idrastru =WMSA08.1938.KUTH96.08897

[25] Archiv Zeměměřického úřadu. Letecké měřické snímky, WMSA08.1960.KUTH95.03582 [on-line]. [cit. 11. červenec 2021]. Dostupné z: https://ags.cuzk.cz/archiv/openmap.html?typ=Ims\&idrastru =WMSA08.1960.KUTH95.03582

[26] Laboratoř geoinformatiky Fakulty životního prostředí Univerzity J. E. Purkyně v Ústí nad Labem.. II. vojenské mapování - Čechy, mapový list O_9_V [on-line]. [cit. 3. srpen 2021]. Dostupné z: http://oldmaps. geolab.cz/map_viewer.pl?lang=cs\&map_root=2vm\&map_region=ce\&map_list=O_9_V (c)2st Military Survey, Section No. O_9_V. Austrian State Archive/Military Archive, Vienna ( Laborator̆ geoinformatiky Univerzita J. E. Purkyně - http://www.geolab.cz@ Ministerstvo životního prostředi ČR-http://www.env.cz

[27] Archiv Zeměměřického úřadu. Císařské povinné otisky stabilního katastru 1:2880 - Čechy, 4759-1 Mlékovice, list 2 [on-line]. [cit. 3. srpen 2021]. Dostupné z: https://ags.cuzk.cz/archiv/openmap. html?typ=cioc\&idrastru=B2_a_6C_4759-1_2

[28] Archiv Zeměměřického úřadu. Topografické mapy v systému S-1952 1 : 10 000, list D7_2__M-3379-A-a-1 [on-line]. [cit. 11. červenec 2021]. Dostupné z: https://ags.cuzk.cz/archiv/openmap.html?typ= topo1952\&idrastru=D7_2__M-33-79-A-a-1

[29] Archiv Zeměměřického úřadu. Topografické mapy v systému S-1952 1:25 000, list D7_3_M-3379-A-a [on-line]. [cit. 13. červenec 2021]. Dostupné z: https://ags.cuzk.cz/archiv/openmap.html?typ=t opo1952\&idrastru=D7_3__M-33-79-A-a

[30] Archiv Zeměměřického úřadu. Státní mapa $1: 5$ 000, list Uhlîrské Janovice 0-0, rok 1969 [on-line]. [cit. 13. červenec 2021]. Dostupné z: https://ags.cuzk.cz/archiv/openmap. html?typ=sm5\&idrastru=D6-1_Uhlirske_Janovice_0-0_1969

[31] RUSSNÁK, J., STACHOŇ, Z., KONEČNÝ, M. Digitalizace mapové sbírky Geografického ústavu Masarykovy univerzity. In: Čada, V. et al. (eds.). Sborník abstraktů príspěvků ze semináre Geomatika vprojektech 2014. Brno: Tribun EU, s. r. 0., 2014. s. 56-57. ISBN 978-80-263-0796-9.

[32] RUSSNÁK, J., STACHOŇ, Z., KONEČNÝ, M. Využití tematických informací ze starých map. In: Vondráková, A., Brus, J., Voženílek, V. (eds.). Sborník abstraktů z 21. kartografické konference. Olomouc: Kartografická společnost ČR, 2015. s. 55. ISBN 978-80-260-8586-7.

[33] HAVLIČEKE, M., SKOKANOVÁ, H., DAVID, V., PAVELKOVÁ, R., LÉTAL, A., FRAJER, J., NETOPIL, P., SARAPATKA, B. Možnosti využití starých topografických map z let 1763-1768 pro hodnocení vývoje vodních ploch a potenciál jejich obnovy. Vodohospodárské technicko-ekonomické informace, 2019, 61(1), s. 6-13. ISSN 0322-8916.

[34] TRPÁKOVÁ, I. Krajina ve světle starých pramenů. Kostelec nad Černými lesy, Lesnická práce, s. r. o., 2009, 1. vydání, 248 s.

[35] KUPKA, J., Krajiny kulturní a historické. Vliv hodnot kulturní a historické charakteristiky na krajinný ráz naši krajiny, 1. vydání., Praha: České vysoké učení technické v Praze, 2010, 179 s.

[36] SEMOTANOVÁ, E. Mapy Čech, Moravy a Slezska v zrcadle staletí. Nakladatelství Libri, Praha, 2001, 1. vydání, $264 \mathrm{~s}$.

[37] SEMOTANOVÁ, E. Historická geografie českých zemí. Praha: Historický ústav AV ČR, 2002, 2. vydání, 280 s.

[38] SEMOTANOVÁ, E. Historická krajina Česka a co po ní zuistalo. Historický ústav AV CR, v. v. i. $\checkmark$ Nakladatelství Academia, Praha, 2014, 1. vydání, 24 s.

[39] MOREIRA, F., QUEIROZ, A. I., ARONSON, J. Restoration principles applied to cultural landscapes. Journal for Nature Conservation, 2006, 14, s. 217-224

[40] LIPSKÝ, Z. et al. Vývoj krajiny Novodvorska a Žehušicka ve středních Čechách 1. ed., Praha: Karolinum, 2011, 204 s. ISBN 978-80-246-1905-7.

[41] LIPSKÝ, Z. et al. Současnost a vize krajiny Novodvorska a Žehušicka ve středních Čechách 1. ed., Praha: Karolinum, 2013, 408 s. ISBN 978-80-246-2075-6.

[42] TRPÁKOVÁ, I., TRPÁK, P., SKLENIČKA, P., SKALOŠ, J., ENGSTOVÁ, B. Rekonstrukce historického využití krajiny Sokolovska - Krajina v zrcadle map stabilního katastru. Lesnická práce, s. r. 0., 2009, 107 s.

[43] GIMMI, U., LACHAT, T., BÜRGI, M. Reconstructing the collapse of wetland networks in the Swiss lowlands 1850-2000. Landscape Ecology 26 (8), 2011, s. 1071-1083

[44] Zákon č. 139/2002 Sb., o pozemkových úpravách a pozemkových úřadech v platném znění

[45] Vyhláška č. 13/2014 Sb., o postupu při provádění pozemkových úprav a náležitostech návrhu pozemkových úprav $\vee$ platném znění

[46] Zákon č. 114/1992 Sb., o ochraně prírody a krajiny v platném znění

[47] Vyhláška č. 395/1992 Sb., kterou se provádějí některá ustanovení zákona č. 114/1992 Sb., o ochraně prírody a krajiny v platném znění

[48] Nařízení vlády č. 50/2015 Sb., o stanovení některých podmínek poskytování prímých plateb zemědělcưm v platném znění

[49] Nařízení vlády č. 48/2017 Sb., o stanovení požadavků podle aktů a standardů dobrého zemědělského a environmentálního stavu pro oblasti pravidel podmíněnosti a důsledků jejich porušení pro poskytováni některých zemědělských podpor v platném znění 


\section{Autoři}

Ing. Pavel Richter, Ph.D.

$凶$ pavel.richter@vuv.cz

ORCID: 0000-0001-6338-3481

Výzkumný ústav vodohospodářský T. G. Masaryka

Přispěvek prošel lektorským řízením.

DOI: 10.46555/VTEI.2021.07.002

\section{PROBLEMATICS OF ARCHIVE MAP \\ DATA INTERPRETATION, SPECIFICALLY THE WETLAND HABITATS}

\section{RICHTER, P.}

T. G. Masaryk Water Research Institute

Key words: archival maps - wetlands - water retention in the landscape floodplains of watercourses - ponds

The article presents available on-line archive maps from the websites of the Archive of the Surveying Office and the Geoinformatics Laboratory of the J. E. Purkyně University, that provide an overview of the historical wetland habitats location. The main research question is to find out the potential use of historical maps for the identification of the historical wetlands in the Czech Republic and the evaluation of various interpretations of wetland habitats based on these sources. Examples of wetlands on historical map data in the upper part of the Výrovka River basin are presented. 